\title{
The mechanism of public administration of the travel industry development: prospects for the ecotourism development
}

\author{
Lyudmyla Kraynyuk ${ }^{1}$, Olena Uhodnikova ${ }^{1}$, ${ }^{*}$, Nataliia Vlashchenk $^{1}$, Anna Sokolenko ${ }^{1}$, and \\ Kostiantyn Viatkin ${ }^{1}$ \\ ${ }^{1}$ O.M. Beketov Kharkiv National University of Urban Economy, Marshala Bazhanova Str. 17, \\ 61002, Kharkiv, Ukraine
}

\begin{abstract}
The paper is devoted to searching ways of efficient support of public administration of the travel industry development. Tourism system has its own specific peculiarities, which influence the implementation of the functions of public administration. Among such peculiarities there are high commercialization of the branch, financial performance of investments and investment attractiveness. The paper considers trends of travel industry development, among which there are tendencies towards the increase of number of tourists, growth of tourist flow and income from travels. Trends of the travel industry development were analysed according to definite parts of the world. Also, trends in the development of ecoturism are considered. As a result of the analysis conducted the negative impact of various factors on the tourism development and aspects of improvement of the effectiveness of tourist activities. On the basis of the analysis conducted among the leading countries of the world according to the statistical data with regard to visiting by tourists, basic approaches to the construction of systems of public administration of the travel industry development were determined. Based on this analysis the proposals were made as to the improvement of public administration system in the sphere of tourism; they can be applied at the global and regional levels in order to maximize implementation of the travel industry potential and socioeconomic functions, being performed thereby in the society. The relevance of the development of ecotourism is determined, which is associated with the solution of global environmental problems.
\end{abstract}

\section{Articulation of Issue}

Travel industry is characterized by high level of commercialization. Low barrier to entry trade and high financial performance of investments ensures business focusing on investments precisely in the travel industry. As a multiplication industry, tourism provides high income into budgets of various levels: state, regional, local. Moreover, it ensures formation of the country reputation at the international scene. Many countries, which

\footnotetext{
*Corresponding author: ugodnikova16@gmail.com
} 
dynamically develop the travel industry, were able to lift economy out of recession and provide a new vector of economic development of the country aimed at the improvement of service sector on the basis of using tourism and recreation potential of territories. Development of the travel industry promotes the increase of number of jobs, therefore, the rate of unemployment and social tension is decreased, and social standard of living is improved. Tourism promotes the development of tolerance by means of familiarization of foreigners with various cultures, national traditions and lifestyle pattern, facilitates searching ways of solving political conflicts, because the travel industry can be developed only subject to the safe stay of tourists at tourist attractions and tourism and recreation territories. Thus, attention of the government to the travel industry provides implementation of financial and economic, integration and social function of the public administration system.

According to official statistics in 2017, the number of tourists all over the world is increased by $7 \%$. In comparison with 2016 this figure increased by 84 million of persons and as of today it makes up 1 billion 323 million of tourists. Forecasts of the World Tourism Organization concerning the global development of the travel industry were just up to 3,8 per cent annually. Therefore, tourism has faster rates of growth, than it was forecasted by the international institutions. This is a general tendency, which is being viewed over several decades. General income from tourism makes up 1340 billion US dollars [1]. Thus issues related to the support of public regulation of economic system development processes shall pay attention to high rates of financial and economic activity in the travel services market, and government program focused on the economy system development shall be established taking into consideration search new methods of implementation of tourist potential of territories. Therefore, an issue related to the improvement of the effectiveness of public regulation of the travel industry is quite urgent and requires further study.

\section{Analysis of the Latest Researches and Publications}

Worldwide network of the travel industry development is shown in the reports and events of the World Tourism Organization [1, 2]. As one of the organizations within the United Nations organization, the World Tourism Organization is responsible for the development of tourism at the global level, forming on the basis of analysis of trends and tendencies of the industry strategic pathways of its development. At the territorial level the management processes of tourist development are represented by various non-governmental organizations and associations, formed by specialists in the sphere of travel industry for the purpose of searching efficient mechanism of development at the local level [3-6, 10, 12]. A number of scientists, in particular, D.R. Makieieva, A.P. Durovych, N.I. Kabushkin, V.S. Bogoliubov, I.V. Arakhamiia, Ie.L. Pysarevskyi etc. dealt with problems related to the analysis of public administration system of the travel industry development $[8,9,11,13$, 14]. However, rapid changes within the competitive environment development at the global level require further study of issues concerning the construction of efficient system of public administration in the sphere of travel industry.

\section{Purposes and Objectives}

For the purpose of this paper, methods of improvement of the public administration effectiveness in the travel industry through the analysis of global experience of tourist development to ensure stable economic development at the level of individual state and at the global economic level . 
According to the purpose in hand, a number of tasks is emphasized:

- to analyse trends of development in the travel industry;

- to define tourist development trends region-wise;

- to analyse basic problems of tourist development;

- to accumulate prospects of socio-economic development for the countries, developing travel industry,

- to define methods of improvement of the public administration effectiveness in the travel industry at a global scale.

\section{Statement of Basic Materials}

Development of the travel industry is accompanied with stable trends towards increase of basic financial and economic rates and tourist flow ramp-up both region-wise and at a global scale. As of today according to the statistical data of the World Tourism Organization the general tourist flow in the world makes up 1 billion 340 million tourists, fixed in 2017. Volumes of tourist flow go up and up, exceeding anticipated growth rate almost twice. At the average increase of number of tourists in the world made up $7 \%$ in 2017. At the same time, the maximum growth record was demonstrated by the European countries ( 671 million, increase by $8 \%$ ) and Africa (63 million, increase by $9 \%$ ). Per cent of growth of tourist flow in America is lower than the overall average which is equal only to $4 \%$, however, in figures this rate makes up 209 million tourists [1].

The majority of tourists prefer travel in order to have a rest and spend leisure, choosing regions with favourable physical and climatic conditions and available tourism and recreation resources. The second place among the tourist trips' motives is taken by trips to friends, relatives and family members (27\%). However, in developing countries business trips prevail over tourist trips. In general, business travel takes the third place among the motives of trips and reaches $13 \%$ of the total number of tourists' motives [2].

The main trends in the development of travel industry region-wise can be presented in terms of scheme as follows [2-7]: fig. 1,

1. Tendency towards changing volumes of tourist flows in Europe, 1995-2017 yrs. -

2. Tendency towards changing volumes of flows in Asia and the Pacific Islands, 19952017 yrs. - fig. 2 ,

3. Tendency towards changing volumes of flows in America, 1995-2017 yrs. - fig. 3

4. Tendency towards changing volumes of flows in Africa, 1995-2017 yrs. - fig. 4

5. Tendency towards changing volumes of tourist flows in the Middle East, 1995-2017 yrs. - fig. 5

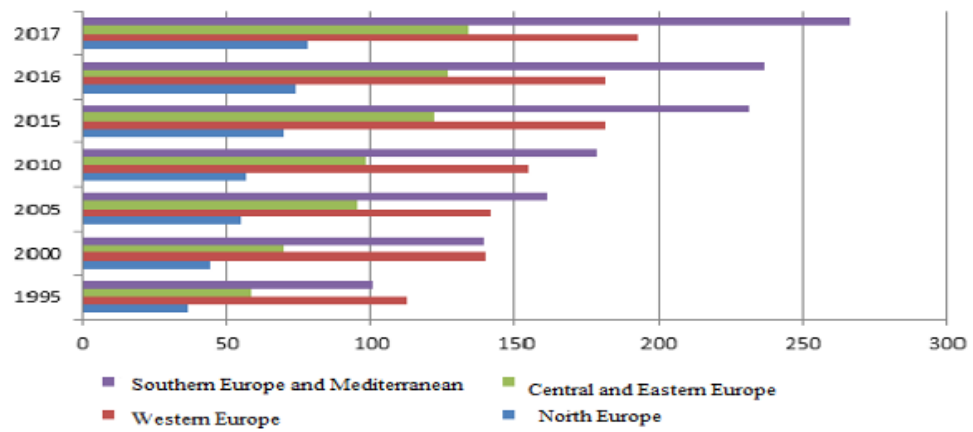

Fig. 1. Tendencies towards the growth of tourist flows by regions in Europe, millions of tourists, 1995-2017 years. 
The diagram (fig. 1) shows that the general tendency towards the growth of tourist flow has been observed in Europe by all regions since 1995. The maximum growth of tourist flow is observed over the last years in the Southern Europe and Mediterranean region, approximately 4, $3 \%$, while on the average in Europe tourist flow annually grows by 3,2 $\%$. Analytics of the travel industry expect the further growth of number of tourists in the Mediterranean countries and to the south of Europe, according to forecast the flow by 2020 shall be 420 million tourists per year [6]. According to the experts this region accepts $32 \%$ of all tourist flows in the world because of powerful tourism and recreation resources and high level of transport accessibility, successful location in terms of ease of arrival from across the world, as well as economic aircraft support for flights.

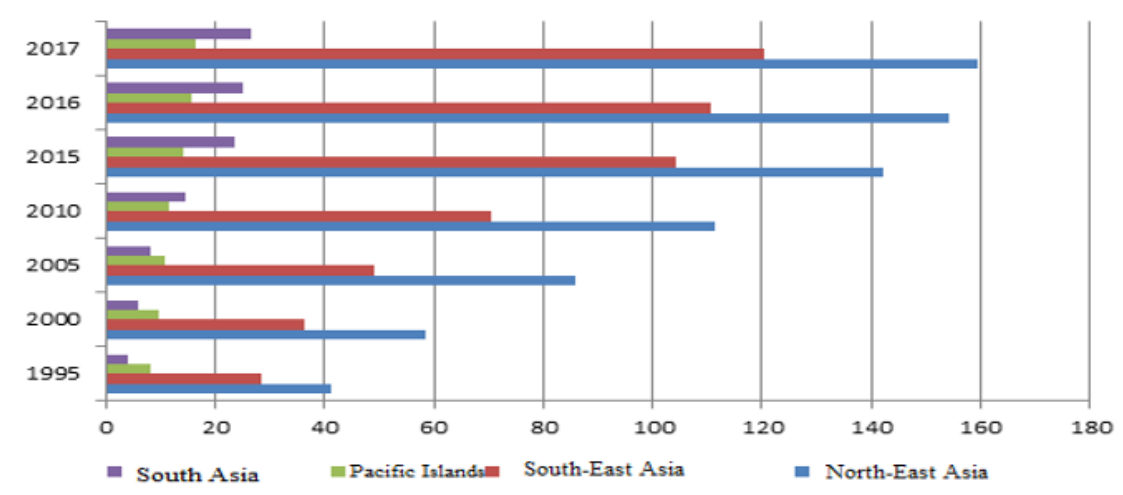

Fig. 2. Tendencies towards the growth of tourist flows by regions of Asia and the Pacific Islands, millions of tourists, 1995-2017 years.

According to the diagram (fig. 2) we can see that trips to the North- and South-East Asia enjoy the greatest popularity. Tendencies towards the growth of tourist flows are observed in all directions. On the average the volumes of growth of tourist flows make up over $10 \%$. The maximum rates of growth are in the regions of the South-East Asia $(7,8 \%)$, and the minimum one is in the Pacific Islands, namely 3,6. This fact can be explained by the complexity of transport accessibility of the region because of the farness from other regions of the world and isolation of territory because the ocean. Notwithstanding the essential rates of growth, the Asia region has higher potential for the tourist flow ramp-up. Negative factor of the tourist development in Asia is political instability, military conflicts and terroristic threat in some countries.

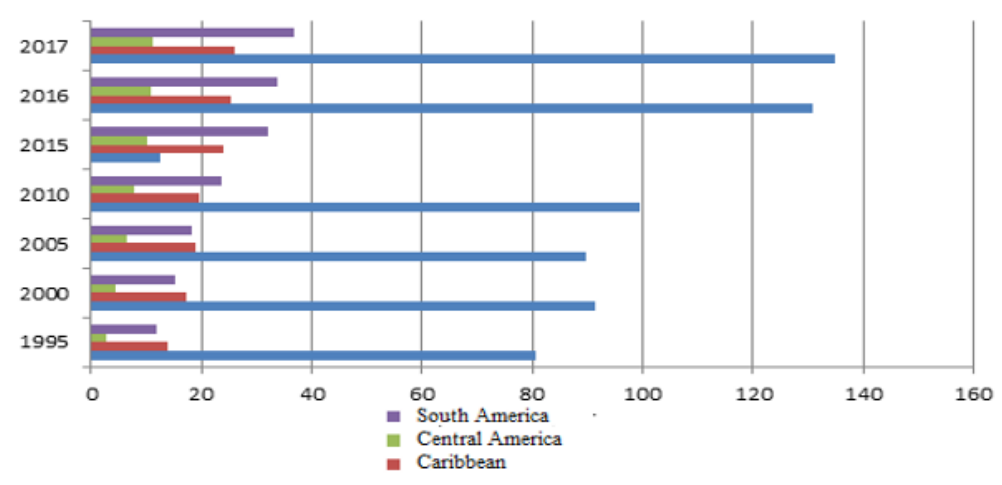

Fig. 3. Tendencies towards the growth of tourist flows by regions of America, millions of tourists, 1995-2017 years. 
On the average growth in new tourists by regions of America is equal to $6 \%$. At the same time, the maximum rate was fixed in the Central regions, it was equal to $4,9 \%$ due to the unique climate and environmental conditions and great tourism and recreation potential. During the period of 2000 to 2005 there was reduction in the number of tourists in the countries of North America. Such a situation, which conflicts with the basic tendencies of tourist development, has arisen because of terroristic threat, which became a reality on the 11th of September, 2001. The buildings of the United States of America were attacked by terrorists on aircrafts. Panic and risks of new terroristic act caused significant reduction of number of passengers of airline companies in North America. Volume of departures of Americans to the European countries was reduced by $30 \%$. Volumes of flows of domestic tourists were reduced by $60 \%$. Visits of Americans to the Caribbean countries (this is a principle category of tourists in these countries) were reduced to one-third of its original value. Such essential rates of reduction in the number of tourists are attributed to the fact that the main transport mode in trips of Americans is aircraft as the most comfortable transport mode due to the geographical position of USA, requiring flights to other countries. Volumes of tourist flows failed in a bid to be increased by 2005 . Increasing tendency was recovered in 2010.

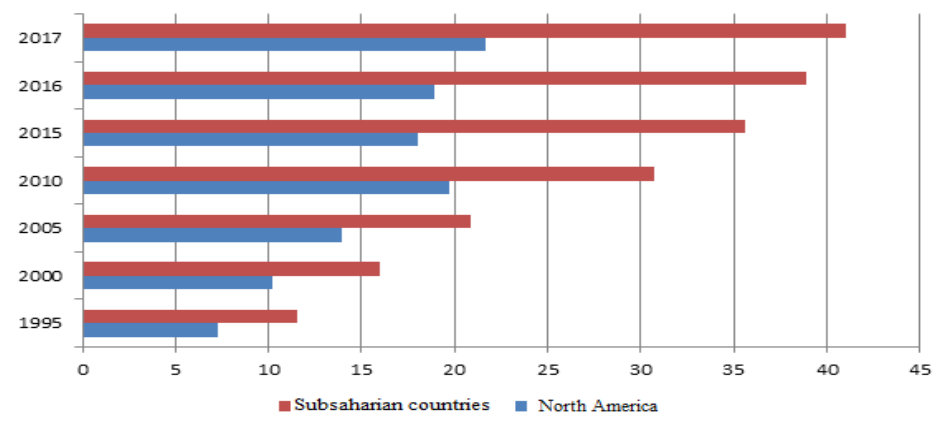

Fig. 4. Tendencies towards the growth of tourist flows by regions of Africa, millions of tourists, 1995-2017 years.

Countries southwards from Sahara (subsaharian region) show analogous to worldwide trends of growth of tourist flows. However, because of low standard of living of population the statistics predominately consists of arriving tourists, who travel to this region in order to see exotic landscapes and natural environment. Domestic tourists travel mainly for the purpose of business for short period of time. Tourist flow development trend in the countries of North Africa, namely, Algeria, Tunisia, Morocco, Sudan is characterized by reduction in 2015-2016. Political instability in Algeria caused by the health deterioration of the president and struggle for power, which was transformed into political coup and conditions for intercommunal conflict development, making it unsafe to stay in the country, all this led to reduction of number of tourists. Reduction of tourist flow in Tunisia was caused by the bloody terrorist attack in the country in 2015, aimed immediately at tourists, who were having vacation by the sea. Tourists were shot down right at the beaches of the Tunisian hotels, resulting in panic and reduction of tourist flows to the country, their recovery took place in 2017. In Sudan as a result of coup and public resistance united nations mission was based, focused on the regulation of political and military conflict for the purpose of prevention of escalation in violence. Sudan is potentially unsafe for tourists, whereof diplomatic missions warn their citizens, demanding to hold back from trips to this country. Only tourist flows to Morocco keep going to be stable, because this country is stable in a political sense in this region. 


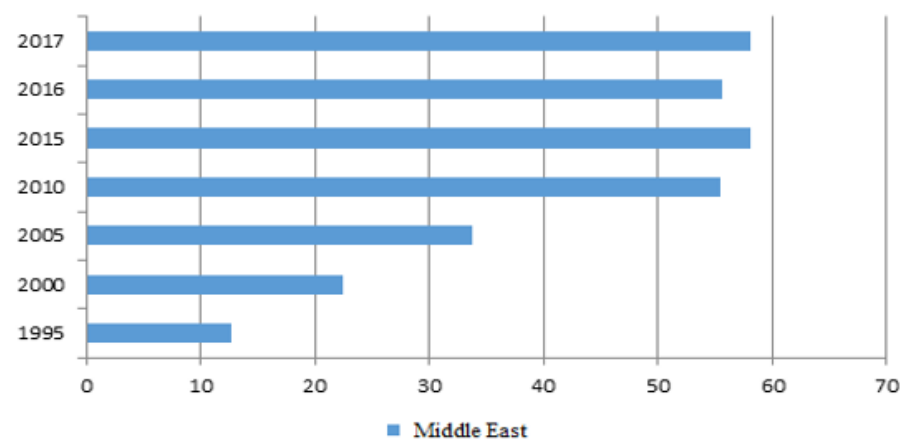

Fig. 5. Tendencies towards the growth of tourist flows by regions of the Middle East, millions of tourists, 1995-2017 years.

There is a tendency towards of growth of tourist flows in the Middle East, except for the period of year 2015. This is due to the terroristic threat and military conflicts, which destabilize the situation in the region. In particular, statistical data concerning the volumes of tourist flows into Syria, Libya, Iraq, Yemen has been absent since 2015 against the background of military and intercommunal conflicts, as well as acts of international military forces in these territories. Reduction of tourist flows is observed in Egypt, Kingdom of Jordan and Palestine because of high level of terroristic threat and acts of a terrorist nature, including in touristy places. Therefore, we can present in tabular format the trend of changes in the number of tourists in the countries, where we can observe local military acts or high level of terroristic threat set down in plat, see Table 1.

Table 1. Tendencies of tourist development in the Asian countries with high level of terroristic threat and local military operations.

\begin{tabular}{|c|c|c|c|}
\hline \multirow{2}{*}{ Country } & \multicolumn{3}{|c|}{ Tourist flow in comparison with the previous year, \% } \\
\cline { 2 - 4 } & 2015-2016 years & 2016-2017 year & 2017-2018 year \\
\hline Syria & N/A & N/A & N/A \\
\hline Egypt & $-42,5$ & 55,1 & 14,0 \\
\hline Iraq & N/A & N/A & N/A \\
\hline $\begin{array}{c}\text { Kingdom of } \\
\text { Jordan }\end{array}$ & $-5,2$ & 7,7 & 6,6 \\
\hline Libya & N/A & N/A & N/A \\
\hline Lebanon & 11,2 & 10,0 & 3,2 \\
\hline Palestine & $-7,4$ & 25,7 & 0,9 \\
\hline Yemen & N/A & N/A & N/A \\
\hline
\end{tabular}

Therefore, according to the table data we can see that the countries, where are overt acts of war, are not taken into consideration when defining tourist flows, since this industry is not developing in these regions. Counties with high level of terroristic threat and danger of political and civil conflicts suffer from significant reduction of tourist flows.

Therefore, the main reasons, which have a negative impact on the tourist development at a global level, can be political instability, high level of terroristic threat, local military conflicts and failure of international institutions to introduce efficient methods of influence on the conflict resolution process that cannot guarantee safe stay in the countries, where such events take place. 
In regions, where travel industry is dynamically developed, there are following improvements in socio-economic life of population [1, 2]:

- economic growth caused by attraction of supplement investments into travel industry and auxiliary branches of economy,

- increase of number of jobs (as of today, one in ten working person in the world is involved in travel industry),

- economic integration and economic cooperation (travel industry makes up 7\% of the general export and $10 \%$ of global GDP),

- cultural development and reduction of discrimination by means of creation of conditions of tolerant attitude to various nationalities and cultures,

- environmental development,

- improving safety of stay in a country, since public authorities of countries, which core business line is tourism, understand the significance of safety for arrivals as a priority of socio-economic development.

Therefore, tourist development can provide socio-economic development of country by means of the factors as follows:

- investment growth,

- guarantee of economic growth of auxiliary branches of economy: building and construction, hospitality industry, restaurant business, agricultural industry, transport etc.,

- expansion in the number of jobs, including for personnel having insufficient qualification,

- cultural development, tolerance level increase and discrimination level decrease,

- de-escalation of social tensions in society, reduction of level of marginal manifestation,

- security upgrade,

- GDP growth,

- improvement of international links and integration into global economic, cultural and educational system,

- development of transport connection and infrastructural development.

For purpose of improvement of efficiency of the travel industry administration mechanisms at the domestic level of some countries, let us determine underlying mechanisms of public administration, peculiar for government systems of the most popular among tourists of countries. Country rating according to the popularity among tourists and short description of specific nature of national influence on the travel industry is presented in Table 2.

Therefore, having analysed basic models of public administration of travel industry among leading countries according to the number of visits by tourists, the following approaches to the implementation of the public administration functions can be distinguished:

- accurate administration of tourism development (PRC),

- absence of centralized administration of industry, transfer of functions of government regulation to the local level under the conditions of open competition (USA),

- implementation of representation functions and functions of standardization and control (European countries, Thailand),

- planning and guaranteeing the travel industry development subject to high level of the industry financing from state budget (Turkey and Mexico).

Therefore, it is found out that in the market economy environment it is reasonable to separate functions of public administration between the following stakeholders:

- public authorities which carry out basic coordination, setting priorities of tourist development, thus, creating "rules of the game" through the standards of quality and system of authorization procedures and positioning of country in the international tourist markets; 
- local authorities (which are involved into the development and implementation of local programs of tourist development),

- public institutions - field-oriented associations, which together with public authorities implement functions of quality monitoring and control of tourist service rendering, development of projects of the travel industry development.

Table 2. Public administration of tourist development in the most popular among the tourists countries of the world in 2018 [7-9].

\begin{tabular}{|c|c|c|}
\hline Country & $\begin{array}{l}\text { Number of } \\
\text { tourists per } \\
\text { year, mln }\end{array}$ & Peculiarities of public administration of the industry \\
\hline France & 86,9 & $\begin{array}{l}\text { The hierarchy of travel industry public administration in France is headed by the relevant } \\
\text { ministry, which fulfils functions of control and audition. Representative body of the Department } \\
\text { of Tourism is Tourism General Inspectorate, which provides the representation of the country } \\
\text { reputation as a tourist centre abroad and controls the work of international travel establishments } \\
\text { and organizations, engaged in promotion of French tourist brand all over the world. } \\
\text { Development of tourism is defined by projects and programs of five-year planning. Every five } \\
\text { years central government authorities shall conclude agreements with local bodies concerning the } \\
\text { joint development of travel industry. The government supports local initiatives in the travel } \\
\text { industry development. Positioning of France in the international travel markets takes precedence. }\end{array}$ \\
\hline Spain & 81,8 & $\begin{array}{l}\text { Spain has no relevant ministry. System of public administration provides for fulfilment of } \\
\text { functions of public administration and control through the multifunctional Ministry of Economic } \\
\text { Development. In its public regulatory policy Spain treats the system of quality of service as high } \\
\text { priority. There is Institute for Travel Quality, which ensures homogeneity of approaches to the } \\
\text { formation of qualitative travel product among the representatives of private sector of this } \\
\text { industry. }\end{array}$ \\
\hline USA & 76,9 & $\begin{array}{l}\text { Because of cuts in expenditures of the federal budget in the USA in } 1997 \text { central government } \\
\text { bodies were winded up, which were responsible for tourist development. Functions of the } \\
\text { development were transferred individually to each state. Furthermore, introduction of projects is } \\
\text { actively supported at local level. Under the conditions of federal structure and high level of open } \\
\text { competition the policy concerning travel industry public administration liberalization responds } \\
\text { favourably. }\end{array}$ \\
\hline China & 60,7 & $\begin{array}{l}\text { Main public body in the travel industry is State Department of Tourism, which accumulates } \\
\text { many regulatory functions taking into consideration peculiarities of political and economic } \\
\text { system of P. R. China, in particular: development of legal framework and standards of tourism } \\
\text { activity, development of tourism development strategy and control of its implementation at the } \\
\text { local level, planning and monitoring of tourism industry development, analysis of statistics and } \\
\text { information generation to substantiate managerial decision-making, P. R. China representation at } \\
\text { the international level as a tourist resort area. }\end{array}$ \\
\hline Italy & 58,3 & $\begin{array}{l}\text { Italy has no relevant ministry. System of public administration provides for fulfilment of } \\
\text { functions of public administration and control through the multifunctional Ministry of } \\
\text { Business. }\end{array}$ \\
\hline Mexico & 39,3 & $\begin{array}{l}\text { It has clear structure of public control and monitoring of process of the plan figure achievement } \\
\text { in tourist development. Significant financial investments are made from the state budget and } \\
\text { budgets of various levels to support representation of travel potential of the country in the } \\
\text { international level and for the purpose of tourist development projects. }\end{array}$ \\
\hline $\begin{array}{c}\text { Great } \\
\text { Britain }\end{array}$ & 37,7 & $\begin{array}{l}\text { The relevant ministry is the Ministry of National Heritage, which fulfils the function as follows: } \\
\text { financial support of the industry, coordination across agencies when implementing projects } \\
\text { focused on tourist development, representation of the country at the international travel market, } \\
\text { standards development and improvement of the effectiveness of domestic travel. }\end{array}$ \\
\hline Turkey & 37,6 & $\begin{array}{l}\text { There is a rigid hierarchic system of public administration, the main functions are monitoring } \\
\text { and control of compliance with the requirements of legislation in the sphere of travel business. } \\
\text { Main control body is the relevant Ministry. The state budget invests massively in the tourist } \\
\text { development programs, country market promotion projects and programs are implemented in the } \\
\text { international tourist markets. Tourism is one of the priorities of the national socio-economic } \\
\text { policies. }\end{array}$ \\
\hline Germany & 37,5 & $\begin{array}{l}\text { Federal structure is favourable for the formation of tourism development policy at local levels. } \\
\text { The government regulates the activity of international representative offices. There are travel } \\
\text { bureaus at the local level, which carry out predominately organization and information function. }\end{array}$ \\
\hline Thailand & 35,4 & $\begin{array}{l}\text { One of the main tasks of public administration in the country is its representation and } \\
\text { popularization in the international markets, development of legal framework, elaboration of } \\
\text { projects and tourism development programs, personnel training for the industry. }\end{array}$ \\
\hline
\end{tabular}

\section{Conclusions}

In summary, as a result of the analysis conducted it was found out that worldwide trends of the travel industry development highlighted the growth of tourist flows in the world and 
increase in income from travels. A of today, tourism is one of the priority sectors of economy, due to which the socio-economic function of country is implemented through allowing for inflow of investments, economic growth, poverty reduction and unemployment, as well as solving other global problems of humanity. Analysis of tourist development trends region-wise allowed defining basic problems, inhibiting the more effective realization of the industry's potential. Such problematic aspects include political instability, terroristic threat and local military conflicts. Travel industry development is one of the instruments of socio-economic stability in some regions subject to the state policy implementation aimed at the support of the tourist development. Collecting experience of building up the public administration system of travel industry in the countries, which are on the top of popularity rating among the tourists, allowed distinguishing four approaches, through the analysis of which we gave recommendations concerning the tourist development by using efficient mechanisms of public administration of the industry.

\section{References}

1. World Tourism Organization, Official site. Electronic resource. - Access mode: http://www2.unwto.org/en

2. UNWTO Tourism Highlights, 2018 Edition Electronic resource. - Access mode:http://tourlib.net/wto/WTO_highlights_2018.pdf

3. European Travel Commission. Electronic resource. - Access mode:https://www.etccorporate.org/.

4. European Travel\&Tourism Advisory Group. Electronic resource. - Access mode:https:// www.eteg-forum

5. European Travel Network Electronic resource. - Access mode:https://metatravel.com/m/groups/view/European-Travel-Network

6. O.I. Uhodnikova, K.I. Viatkin, T.N. Kolesnyk, Public administration's mechanisms of the security management in tourism industry Chernigiv. ChNTY - 2018/ DOI: 10.25140/2410-9576-2018-4(16)-39-46

7. Y. Ming, L. Bertolini, J. Duana, The effects of the high-speed railway on urban development: International experience and potential implications for China https://doi.org/10.1016/j.progress.2013.11.001

8. K. Fladmoe-Lindquist, L. L. Jacque, Control Modes in International Service Operations: The Propensity to Franchise, Published Online: 1Jul 1995https://doi.org/10.1287/mnsc.41.7.1238

9. THE STATE COUNCIL THE PEOPLE'S REPUBLIC OF CHINA http://www.gov.cn/fwxx/bw/lvyj/index.htm

10. S. Andersson, Journal of Small Business and Enterprise Development. ISSN: 14626004, (2006) https://doi.org/10.1108/14626000610705796

11. Official site about tourism in Thailand, https://www.tourismthailand.org/home

12. Antonella Zucchella G. Palamara S. Denicolai Journal of World Busines. The drivers of the early internationalization of the firm https://doi.org/10.1016/j.jwb.2007.04.008

13. AnaRamón Rodríguez Tourism Management Determining factors in entry choice for international expansion. The case of the Spanish hotel industry, 23(6), 597-607 (2002) https://doi.org/10.1016/S0261-5177(02)00024-9 